\title{
Prenatal Attachment Levels and Affecting Factors of Pregnant Women Living in İstanbul and Kars
}

\author{
istanbul'da ve Kars'ta Yașayan Gebelerin Prenatal Bağlanma Düzeyleri ve Etkileyen Faktörler
}

\author{
Özlem Karabulutlu', Kerime Derya Beydağ2, Merve Lazoğlu³ \\ ${ }^{1}$ Department of Midwifery, Faculty of Health Sciences, Kafkas University, Kars; ${ }^{2}$ Okan University Faculty of Health Sciences, Istanbul; \\ ${ }^{3}$ Atatürk University Faculty of Health Sciences, Erzurum, Turkey
}

\begin{abstract}
Aim: This research was carried out to determine prenatal attachment grades and its effecting factors of pregnants living in two different cities placed in the west and east sides of Turkey.

Material and Method: The research was a descriptive type and was carried out in three different hospitals, which served in Istanbul and Kars. The universe of this research has consisted of pregnants applied to those hospitals in told above. A sampling of the research has consisted of 5173 pregnants applied to and agreed on the research in the hospitals above between November 2014 and June 2015. Collecting data 'Personal Information Form' and 'Prenatal Attachment Inventory' were used. Evaluating data, percentage, average and standard deviation, and t-test and ANOVA test were used.
\end{abstract}

Results: Prenatal attachment grades of the pregnants living in Kars city: 60.57 \pm 9.20 ; Prenatal attachment grades of the pregnants living in Istanbul: 59.16 \pm 10.82 . Average prenatal attachment of all pregnants involved in the research $59.89 \pm 10.03$. Prenatal attachment grades of the pregnants who are above 40 years of age, the primary school graduated, are not working, whose income is lesser than their outcomes, live in a crowded house and whose marriage time is more than 11 years, is lower than other participants $(p<0.05)$. Pregnancy numbers of pregnants, situation whether the pregnancy is planned or not, that who decided the pregnancy, living children numbers, having disabled children and the case of getting pregnant with treatment has got meaningful differences with the prenatal attachment of pregnants $(p<0.05)$; there are no meaningful statistical differences with pregnancy month and prenatal attachment grades. ( $p>0.05)$. Prenatal attachment grades of the pregnant who go to controls in fewer times, have no education, and do not make sufficient controls during their pregnancies are stated lower $(p<0.05)$.

Conclusion: It was found that prenatal attachment increased as perceived social support increased in pregnant women. In order to increase prenatal attachment, it is recommended to continue social support to pregnant women.

Key words: pregnancy; prenatal attachment; women; nursing

\section{ÖZET}

Amaç: Bu çalıșma, Türkiye'nin doğusunda ve batısında iki farklı ilde yașayan gebelerin prenatal bağlanma düzeylerini ve etkileyen faktörleri belirlemek amacıyla yapılmıștır.

Materyal ve Metot: Tanımlayıcı nitelikteki araștırma, İstanbul ve Kars'ta hizmet veren üç farklı hastanede yapılmıștır. Araștırmanın evrenini, araștırmanın yapıldığı yılda adı geçen hastanelerin polikliniklerine bașvuran gebeler olușturmaktadır. Araștırmanın örneklemini Kasım 2014 - Haziran 2015 tarihleri arasında çalıșmanın yapıldığı hastanelere bașvuran ve çalıșmaya katılmayı kabul eden 5173 gebe olușturmuștur. Verilerin toplanmasında, "Kișisel Bilgi Formu" ve "Prenatal Bağlanma Ölçeği kullanılmıștır. Verilerin değerlendirilmesinde yüzdelik, ortalama, standart sapma, $t$ testi ve ANOVA testi kullanılmıștır.

Bulgular: Kars ilinde yașayana gebelerin prenatal bağlanma düzeyi puan ortalaması 60,57士9,20; istanbul'da yașayan gebelerin prenatal bağlanma düzeyi 59,16 $\pm 10,82$ olarak bulunmuștur. Araștırmaya dâhil olan tüm gebelerin prenatal bağlanma düzeyi

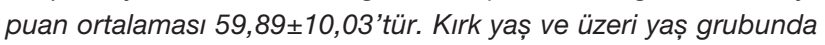
olan, ilköğretim mezunu, bir iște çalıșmayan, geliri giderinden az olan, kalabalık ailede yașayan ve evlilik süresi 11 yıl ve üzeri olan gebelerin prenatal bağlanma düzeyleri daha düșük bulunmuștur $(p<0,05)$. Gebelerin gebelik sayısı, gebeliğin planlı olma durumu, gebelik kararını kimin verdiği, yașayan çocuk sayısı, engelli çocuğu olma durumu ve gebeliğin tedavi ile olma durumu ile prenatal bağlanma ölçeği puan ortalaması arasında istatistiksel olarak anlamlı farklılık saptanmıș ( $p<0,05)$; gebelik ayı ile prenatal bağlanma ölçeği puan ortalaması arasında istatistiksel olarak anlamlı farklılık bulunmamıștır ( $p>0,05)$. Gebeliği süresinde az kontrole giden, eğitim almayan ve gebelik boyunca gerekli testleri yaptırmayanların prenatal bağlanma ölçeği puan ortalamaları daha düșük bulunmuștur $(p<0,05)$.

Sonuç: Gebelerde algılanan sosyal destek arttıkça, prenatal bağlanmanın arttı̆̆ı tespit edilmiștir. Prenatal bağlanmanın artırıması için gebelere verilen sosyal desteğin sürdürülmesi önerilir.

Anahtar kelimeler: gebelik; prenatal bağlanma; kadın; hemșirelik

IIetișim/Contact: Özlem Karabulutlu, Department of Midwifery, Faculty of Health Sciences, Kafkas University, Kars, Turkey • Tel: 05321781081 • E-mail:okarabulutlu@gmail.com • Geliș/Received: 17.10.2019 • Kabul/Accepted: 20.03.2020

ORCID: Özlem Karabulutlu, 0000-0001-7477-3450 • Kerime Derya Beydă̆, 0000-0002-7251-4882 • Merve Lazoğlu, 0000-0002-0376-532X 


\section{Introduction}

The most crucial decision of humans in their lifetime is having a baby. A wish of being a mother bears great importance in women's life. Having babies provides continuing human generations. Whereas pregnancy is a physiological process in which women live important biological differences, it is also a process that can be defined as a sociological, physiological, complex crisis. It is important that adopting a mother role in the future in the meantime ${ }^{1}$.

Muller ${ }^{2,3}$ defines prenatal attachment as an absolute relationship between a mother and her unborn baby.

Rubin researched gaining the mother role of women and reported that the importance of the prenatal process in having an instant relationship between mother and her baby after birth is excellent levels. In this research, he detected that the relationship between a mother and her baby is a behavior that develops after the prenatal process. Based on his observations, he defines that there are four different duties of women before birth. According to him, these are searching for a safe transition both for baby and mother, providing expecting as a special one by other individuals, bonding to baby, and giving herself to baby ${ }^{4}$.

According to Cranley ${ }^{5}$, the definition of maternal-fetal bonding is that; a woman who creates a close relationship with her unborn baby by her behaviors. Peppers and Knapp ${ }^{6}$ offer that bonding of woman and the unborn baby started in the prenatal process, not in the neonatal process, and they contribute to the development of the process.

The most critical stage of bonding of mother and an unborn baby starts in just before the birth, and it continues in the following times after birth. Bonding a safe relationship between mother and baby bears great importance in the social and emotional development of baby $^{7,8}$. In a bonding relationship, the mother is a key factor. In a mother-baby relationship, the more mother and baby react against their behaviors, the more the quality of their relationship is. Some researchers offer that consistency of mother and baby relationship also creates the base of future lives. The earlier and healthier the relationship between mother and baby starts, the stronger the emotion of mothers are. This special bondings of a mother with a baby are the most important determinant in baby's spiritual development ${ }^{9,10}$.

Forming of mother and baby bondings, it is stated that there are planning of pregnancy, wishing for pregnancy, trusting emotion of mother, socio-economical and cultural situation of the family, spousal relations, spouse supports, family, and social relations of woman factors ${ }^{11}$.

It is essential to detect the mother-fetus bonding level. Because it is possible to help pregnant ones who bear weak bonding risk, act recklessly, or have no information about bonding by education and motivation. Nurses have got significant pay in adopting positive pregnancy and birth experience on pregnants. Effective prenatal caregiving to pregnants increases the positive fetal results by raising the prenatal process and, afterward, life quality. Nurse helps pregnant women by decreasing the concerns of mother candidates, giving a positive perspective about being a mother and overcoming prejudices about mother behaviors. These cases make learning the mother's behavior process easier. Detecting risky mother candidates during pregnancy and helping mother candidates about emotional bondings are essential inside of nurses ${ }^{12}$.

There are some researches about the prenatal attachment of mother and baby in after birth times in our country. However, researches about maternal-fetal bondings in the prenatal era are limited. The aim of this study was carried out to determine prenatal attachment grades and its effecting factors of pregnants living in two different cities placed in the west and east sides of Turkey.

\section{Material and Method}

Before the beginning of the research, permission from Dereli Yilmaz ${ }^{12}$ was requested. After that, an approval from University Ethical Council was received (17.12.2014/56). Application permission was received regarding hospitals. In the scope of research, before collecting data from pregnants, the scope and aim of the research were told. The research is definer and relationseeking featured. The research was carried out with volunteer pregnants in three government hospitals between November 2014-June, 2015. The environment of the research has consisted of pregnants who applied the hospitals and clinics above between told dates and places. Annual and monthly numbers of applied pregnants regarding hospitals for prenatal controls. As so, 5173 patients who applied to regard hospitals regarding dates becomes the environment of the research. Two thousand nine hundred sixty of those live in Kars, and 2483 of those live in Istanbul. Criteria involving in sampling are capable of reading and writing, speaking 
in Turkish, and having no risks in pregnancy. Sociodemographical features and obstetrical features create the independent variables of the research. The prenatal attachment inventory point average creates the dependent variables of the research.

\section{Data Collecting Instrument}

Personal data form: This form was prepared according to regarding literature information by researchers. There is 21 question about demographical and obstetrical features of pregnants.

Prenatal attachment inventory: The scale was prepared in 1993 by Muller ${ }^{2}$, and was adapted to Turkish in 2013 by Kizilkaya Beji and Dereli Yilmaz ${ }^{12}$. This scale has consisted of 21 articles and four Likert scales. Every article is marked between 1 and 4, then a minimum of 21 and a maximum of 84 points can be got at the end of the test. The more point the pregnant gets from the scale, the more she can bond to her baby. These numbers are pointed as follows. 1: Never, 2: Sometimes, 3: Frequently, 4: Always. Dereli Yilmaz and Kizilkaya Beji ${ }^{12}$ determined the total Cronbach alfa coefficient as 0.84 . In Metin's ${ }^{13}$ research, the coefficient of the scale was determined as 0.86 .

Regarding form and scales were applied by meeting with pregnants face to face without not intervening in their pregnancy treatment process.

\section{Statistical Analyses}

Data were evaluated in SPSS 21 statistic package software. Evaluating data, percentage, average standard deviation, $\mathrm{t}$-test, and ANOVA test were used.

\section{Results}

$36.6 \%$ of the pregnants in the research are between 22-27 years group, $61.5 \%$ of them are primary school graduated, $79.6 \%$ of them do not work, and $70.3 \%$ of whose income and the outcome is equal. $54.9 \%$ of them live with $1-4$ persons in their house, $35.5 \%$ of them have been married for $1-5$ years, $97.2 \%$ of them have got official marriage with their husbands (Table 1).

$37.6 \%$ of pregnants have experienced three times, and above giving birth, $37.5 \%$ of them have got no living child. $2.2 \%$ of them have got a disabled child. $84.8 \%$ of whose pregnancy was planned, $75.7 \%$ of them gave the decision of pregnancy with their husbands $66.5 \%$ of them are in 7-9 months of their pregnancy. $2.8 \%$ of them got pregnant after medical treatment, $47.2 \%$ of them went for control for $1-5$ times during their pregnancy, and $52.4 \%$ of them have got some information from their doctor/nurse or midwife. $66.1 \%$ of pregnants prefer natural birth, $84.5 \%$ of them want to give birth in a public hospital, and $79.1 \%$ of them make their test done during their pregnancy (Table 1).

Prenatal attachment grades of pregnants in the scope of research was illustrated in Table 2. Average prenatal attachment grades of pregnants living in Kars 60.57 \pm 9.20 ; Average prenatal attachment grades of pregnants living in Istanbul 59.16 \pm 10.82 . Average points of prenatal attachment grades of pregnants who attend the research $59.89 \pm 10.03$ (Table 2).

Age groups, education level, and working situations and comparisons of prenatal attachment inventory point average were given in Table 3. A meaningful difference was detected between features with prenatal attachment $(p<0.05)$. Prenatal attachment levels of the pregnants who are in 40 and above years group, the primary school graduated, not working and having less income than outcome, living in a crowded house, and whose marriage times is more than 11 years are lower (Table 3).

Comparison of prenatal attachment scale point average according to pregnancy based features of pregnants and whether having children were given in Table 3. Giving birth times of pregnants, planning situation of pregnancy, who decided the pregnancy, living children numbers, having disabled children and pregnancy with medical treatment has got a meaningful statistical difference with prenatal attachment point average $(p<0.05)$; and there are no meaningful statistical differences with pregnancy month and prenatal attachment scale point average $(p>0.05)$ (Table 3$)$.

Comparison of prenatal attachment inventory point average according to number of doctor controls during pregnancy, having education during pregnancy, and making necessary tests done were given in Table 3. There are meaningful differences between prenatal attachment scale point average and how many times she went for control, having an education, and making necessary tests done during her pregnancy $(p<0.05)$. Lesser number of doctor controls, ones having no education and are not making necessary tests have got lower prenatal attachment scale point average. 
Table 1. Introducer, pregnancy and birth features of pregnants

\begin{tabular}{|c|c|c|c|}
\hline Variables & & Numbers & Percentage \\
\hline Age groups & $\begin{array}{l}16-21 \\
22-27 \\
28-33 \\
34-39 \\
40 \text { and above }\end{array}$ & $\begin{array}{c}882 \\
1892 \\
1424 \\
816 \\
159\end{array}$ & $\begin{array}{l}17.1 \\
36.6 \\
27.5 \\
15.8 \\
3.1\end{array}$ \\
\hline Education level & $\begin{array}{l}\text { Primary } \\
\text { High school } \\
\text { College and above }\end{array}$ & $\begin{array}{c}3179 \\
1244 \\
750\end{array}$ & $\begin{array}{l}61.5 \\
24.0 \\
14.5\end{array}$ \\
\hline Working situation & $\begin{array}{l}\text { Working } \\
\text { Not Working }\end{array}$ & $\begin{array}{l}1054 \\
4119\end{array}$ & $\begin{array}{l}20.4 \\
79.6\end{array}$ \\
\hline Economical situation & $\begin{array}{l}\text { Less income than outcome } \\
\text { Equal income and outcome } \\
\text { More income than outcome }\end{array}$ & $\begin{array}{c}952 \\
3637 \\
584\end{array}$ & $\begin{array}{l}18.4 \\
70.3 \\
11.3\end{array}$ \\
\hline $\begin{array}{l}\text { Individuals living with in the } \\
\text { house }\end{array}$ & $\begin{array}{l}1-4 \\
5-9 \\
10 \text { and above }\end{array}$ & $\begin{array}{c}2841 \\
2018 \\
314\end{array}$ & $\begin{array}{l}54.9 \\
39.0 \\
6.1\end{array}$ \\
\hline Marriage time & $\begin{array}{l}\text { Less than } 1 \text { year } \\
1-5 \text { years } \\
6-10 \text { years } \\
11 \text { years and above }\end{array}$ & $\begin{array}{c}992 \\
1835 \\
1322 \\
1024\end{array}$ & $\begin{array}{l}19.2 \\
35.5 \\
25.6 \\
19.8\end{array}$ \\
\hline Official marriage & $\begin{array}{l}\text { Yes } \\
\text { No }\end{array}$ & $\begin{array}{c}5030 \\
143\end{array}$ & $\begin{array}{l}97.2 \\
2.8\end{array}$ \\
\hline Giving birth times & $\begin{array}{l}\text { First } \\
\text { Second } \\
\text { Third and above }\end{array}$ & $\begin{array}{l}1855 \\
1371 \\
1947\end{array}$ & $\begin{array}{l}35.9 \\
26.5 \\
37.6\end{array}$ \\
\hline Numbers of living children & $\begin{array}{l}\text { No } \\
1 \\
2 \\
3 \text { and above }\end{array}$ & $\begin{array}{c}1938 \\
1400 \\
831 \\
1004\end{array}$ & $\begin{array}{l}37.5 \\
27.1 \\
16.1 \\
19.4\end{array}$ \\
\hline Having disabled children & $\begin{array}{l}\text { Yes } \\
\text { No }\end{array}$ & $\begin{array}{c}114 \\
5059 \\
\end{array}$ & $\begin{array}{c}2.2 \\
97.8\end{array}$ \\
\hline Is it a planned pregnancy? & $\begin{array}{l}\text { Planned } \\
\text { Not planned }\end{array}$ & $\begin{array}{l}4387 \\
786\end{array}$ & $\begin{array}{l}84.8 \\
15.2\end{array}$ \\
\hline Who decided the pregnancy? & $\begin{array}{l}\text { Women herself } \\
\text { Husband } \\
\text { Together } \\
\text { Parents } \\
\text { Unplanned pregnancy }\end{array}$ & $\begin{array}{c}266 \\
470 \\
3914 \\
69 \\
454\end{array}$ & $\begin{array}{c}5.1 \\
9.1 \\
75.7 \\
1.3 \\
8.8\end{array}$ \\
\hline Recent pregnancy month & $\begin{array}{l}1-3 \\
4-6 \\
7-9\end{array}$ & $\begin{array}{c}586 \\
1147 \\
3440\end{array}$ & $\begin{array}{l}11.3 \\
22.2 \\
66.5\end{array}$ \\
\hline $\begin{array}{l}\text { Pregnancy with medical } \\
\text { treatment }\end{array}$ & $\begin{array}{l}\text { Pregnancy with treatment } \\
\text { Natural pregnancy }\end{array}$ & $\begin{array}{c}144 \\
5029\end{array}$ & $\begin{array}{l}2.8 \\
97.2\end{array}$ \\
\hline $\begin{array}{l}\text { How many times did she go for } \\
\text { control during pregnancy? }\end{array}$ & $\begin{array}{l}1-5 \text { times } \\
6-10 \text { times } \\
11 \text { times and above }\end{array}$ & $\begin{array}{l}2443 \\
2405 \\
325\end{array}$ & $\begin{array}{l}47.2 \\
46.5 \\
6.3 \\
\end{array}$ \\
\hline $\begin{array}{l}\text { Having education about } \\
\text { pregnancy }\end{array}$ & $\begin{array}{l}\text { No education } \\
\text { Having education from doctor/nurse/midwife } \\
\text { Having education from internet, TV or newspaper } \\
\text { Other (occupational educations) }\end{array}$ & $\begin{array}{r}1823 \\
2710 \\
432 \\
208 \\
\end{array}$ & $\begin{array}{l}35.2 \\
52.4 \\
8.4 \\
4.0\end{array}$ \\
\hline Preferred giving birth way & $\begin{array}{l}\text { Natural birth } \\
\text { Caesarean birth } \\
\text { Not sure }\end{array}$ & $\begin{array}{l}3421 \\
1506 \\
246\end{array}$ & $\begin{array}{l}66.1 \\
29.1 \\
4.8\end{array}$ \\
\hline Where she wants to give birth & $\begin{array}{l}\text { Home } \\
\text { Private hospital } \\
\text { Public hospital }\end{array}$ & $\begin{array}{c}71 \\
729 \\
4373\end{array}$ & $\begin{array}{c}1.4 \\
14.1 \\
84.5\end{array}$ \\
\hline $\begin{array}{l}\text { Make necessary tests during } \\
\text { pregnancy? }\end{array}$ & $\begin{array}{l}\text { She made. } \\
\text { She didn't make because she expect it is unnecessary. } \\
\text { She didn't make because she didn't know. } \\
\text { She didn't make because she didn't want abortion if necessary. } \\
\text { She didn't make because test time hasn't come yet. }\end{array}$ & $\begin{array}{l}4091 \\
249 \\
382 \\
237 \\
214\end{array}$ & $\begin{array}{l}79.1 \\
4.8 \\
7.4 \\
4.6 \\
4.1\end{array}$ \\
\hline Total & & 5173 & 100.0 \\
\hline
\end{tabular}


Table 2. Prenatal attachment scale point average of the pregnants

\begin{tabular}{lccc}
\hline Living city & numbers & Min. and max. points from scale & Average of points from scale X \pm SS \\
\hline Kars & 2690 & $23-84$ & $60.57 \pm 9.20$ \\
Istanbul & 2483 & $25-84$ & $59.16 \pm 10.82$ \\
Scale Total & 5173 & $21-84$ & $59.89 \pm 10.03$ \\
\hline
\end{tabular}

Table 3. Comparison of prenatal attachment scale point averages of pregnants according to introducer, pregnancy and birth features of pregnants

\begin{tabular}{|c|c|c|c|}
\hline Features & & Prenatal attachment scale $\mathrm{X} \pm \mathrm{SS}$ & Test and $p$ value \\
\hline Age group & $\begin{array}{l}16-21 \\
22-27 \\
28-33 \\
34-39 \\
40 \text { and above }\end{array}$ & $\begin{array}{c}60.68 \pm 9.36 \\
60.13 \pm 9.78 \\
60.16 \pm 10.09 \\
58.53 \pm 10.91 \\
57.21 \pm 10.41\end{array}$ & $\begin{array}{l}\mathrm{F}: 8.512 \\
\mathrm{p}: 0.007\end{array}$ \\
\hline Education level & $\begin{array}{l}\text { Primary school } \\
\text { High school } \\
\text { College or above }\end{array}$ & $\begin{array}{l}59.04 \pm 10.16 \\
61.11 \pm 9.44 \\
61.48 \pm 9.91\end{array}$ & $\begin{array}{l}\text { F: } 30.448 \\
\text { p: } 0.000\end{array}$ \\
\hline Working & $\begin{array}{l}\text { Yes } \\
\text { No }\end{array}$ & $\begin{array}{c}61.25 \pm 9.85 \\
59.54 \pm 10.05\end{array}$ & $\begin{array}{l}\mathrm{t}: 4.944 \\
\mathrm{p}: 0.000\end{array}$ \\
\hline Economical situation & $\begin{array}{l}\text { Less income than outcome } \\
\text { Equal income and outcome } \\
\text { More income than outcome }\end{array}$ & $\begin{array}{l}58.54 \pm 10.44 \\
59.94 \pm 9.91 \\
61.79 \pm 9.82\end{array}$ & $\begin{array}{l}F: 19.220 \\
p: .000\end{array}$ \\
\hline Persons who live with & $\begin{array}{l}1-4 \\
5-9 \\
10 \text { or above }\end{array}$ & $\begin{array}{c}60.51 \pm 9.92 \\
59.04 \pm 10.17 \\
59.78 \pm 9.76\end{array}$ & $\begin{array}{l}F: 12.771 \\
\text { p: } 0.000\end{array}$ \\
\hline Marriage time & $\begin{array}{l}\text { Less than } 1 \text { year } \\
1-5 \text { years } \\
6-10 \text { years } \\
11 \text { years }\end{array}$ & $\begin{array}{c}61.11 \pm 9.78 \\
60.42 \pm 9.38 \\
59.38 \pm 10.27 \\
58.42 \pm 10.85\end{array}$ & $\begin{array}{l}F: 15.256 \\
\text { p: } 0.000\end{array}$ \\
\hline Giving birth times & $\begin{array}{l}\text { First } \\
\text { Second } \\
\text { Third or above }\end{array}$ & $\begin{array}{c}61.28 \pm 9.48 \\
60.12 \pm 9.54 \\
58.40 \pm 10.67\end{array}$ & $\begin{array}{l}F: 40.132 \\
\text { p: } 0.000\end{array}$ \\
\hline Planned or not planned pregnancy & $\begin{array}{l}\text { Planned } \\
\text { Not Planned }\end{array}$ & $\begin{array}{c}60.39 \pm 9.58 \\
57.10 \pm 11.89\end{array}$ & $\begin{array}{l}\mathrm{t}: 8.519 \\
\mathrm{p}: 0.000\end{array}$ \\
\hline Who decided the pregnancy? & $\begin{array}{l}\text { Woman herself } \\
\text { Husband } \\
\text { Together with husbanc } \\
\text { Parents } \\
\text { Unplanned pregnancy }\end{array}$ & $\begin{array}{c}60.49 \pm 10.38 \\
59.57 \pm 10.62 \\
60.53 \pm 9.47 \\
56.85 \pm 9.03 \\
55.11 \pm 12.42\end{array}$ & $\begin{array}{l}F: 32.035 \\
\text { p: } 0.000\end{array}$ \\
\hline Recent pregnancy months & $\begin{array}{l}1-3 \\
4-6 \\
7-9\end{array}$ & $\begin{array}{c}59.35 \pm 11.10 \\
60.37 \pm 10.13 \\
59.82 \pm 9.80\end{array}$ & $\begin{array}{l}\mathrm{F}: 2.238 \\
\mathrm{p}: .107\end{array}$ \\
\hline Living children & $\begin{array}{l}\text { No } \\
1 \\
2 \\
3 \text { or above }\end{array}$ & $\begin{array}{l}61.13 \pm 9.45 \\
59.96 \pm 9.76 \\
58.75 \pm 10.29 \\
58.35 \pm 10.93\end{array}$ & $\begin{array}{l}F: 21.509 \\
\text { p: } 0.000\end{array}$ \\
\hline Having disabled children & $\begin{array}{l}\text { Yes } \\
\text { No }\end{array}$ & $\begin{array}{l}58.36 \pm 11.24 \\
59.92 \pm 10.00\end{array}$ & $\begin{array}{l}\mathrm{t}: 1.643 \\
\mathrm{p}: 0.039\end{array}$ \\
\hline Pregnancy with a medical treatment & $\begin{array}{l}\text { With a treatment } \\
\text { Natural pregnancy }\end{array}$ & $\begin{array}{l}62.94 \pm 11.51 \\
59.80 \pm 9.97\end{array}$ & $\begin{array}{l}\text { t: } 3.702 \\
\text { p: } 0.005\end{array}$ \\
\hline $\begin{array}{l}\text { How many times did she go to } \\
\text { doctor control? }\end{array}$ & $\begin{array}{l}1-5 \text { times } \\
6-10 \text { times } \\
11 \text { times and above }\end{array}$ & $\begin{array}{l}59.45 \pm 10.29 \\
60.12 \pm 9.82 \\
61.47 \pm 9.47\end{array}$ & $\begin{array}{l}\text { F: } 6.968 \\
\text { p: } 0.001\end{array}$ \\
\hline $\begin{array}{l}\text { Having any education about } \\
\text { pregnancy }\end{array}$ & $\begin{array}{l}\text { No education } \\
\text { Education from doctor/nurse/midwife } \\
\text { Education from internet, TV, newspaper } \\
\text { Other (occupational education) }\end{array}$ & $\begin{array}{c}59.01 \pm 10.15 \\
60.25 \pm 10.00 \\
61.89 \pm 9.96 \\
58.83 \pm 8.65\end{array}$ & $\begin{array}{l}F: 12.391 \\
\text { p: } 0.000\end{array}$ \\
\hline $\begin{array}{l}\text { Making necessary test done during } \\
\text { pregnancy }\end{array}$ & $\begin{array}{l}\text { Yes } \\
\text { No }\end{array}$ & $\begin{array}{c}60.38 \pm 9.80 \\
58.06 \pm 10.67\end{array}$ & $\begin{array}{l}\mathrm{t}: 6.801 \\
\mathrm{p}: 0.000\end{array}$ \\
\hline
\end{tabular}




\section{Discussion}

$36.6 \%$ of pregnants are in the $22-27$ age group, $61.5 \%$ of them are primary school graduated, $79.6 \%$ of them are not working, and $70.3 \%$ of whose income and the outcome are equal. 54.9\% of pregnants are living with $1-4$ persons in their house, $35.5 \%$ of them have been married for $1-5$ years, and $97.2 \%$ of them have got official marriage (Table 1). These discoveries show that mothers in this research have got a lower education lev$\mathrm{el}$, have got no economic income, have got a mediumincome level, and newly married.

$37.6 \%$ of pregnants had have three, and above births, $37.5 \%$ of them have got no living children, $2.2 \%$ of them have got disabled children. $84.8 \%$ of pregnants have planned pregnancy, $75.7 \%$ of them made the pregnancy decision with their husband, $66.5 \%$ of them are in the 7-9 month period of pregnancy. $2.8 \%$ of pregnants became pregnant after medical treatment, $47.2 \%$ of them went for control 1-5 times during their pregnancy, and $52.4 \%$ of them obtain information from their doctor/nurse or midwife. $66.1 \%$ of pregnants prefer normal birth, $84.5 \%$ of them prefer giving birth in a public hospital, and $79.1 \%$ of them make their necessary tests done during their pregnancy (Table 1).

In Metin's ${ }^{13}$ research, $44.5 \%$ of pregnants had have three and above giving births, and $74.9 \%$ of them wants pregnancy. In AluşTokat, Okumuş and Dennis' $\mathrm{s}^{11}$ research, $69.3 \%$ of participants give normal birth. Willing to be pregnant is considered beneficial both for mother in pscyhological ways and then milking baby consistently.

Prenatal bonding grades of pregnants were given in Table 2. Prenatal attachment grades of the pregnants living in Kars city 60.57 \pm 9.20 ; prenatal attachment grades of the pregnants living in Istanbul 59.16 \pm 10.82 . Average prenatal attachment of all pregnants involved in the research $59.89 \pm 10.03$ (Table 2). There are some similar researches in literature. In Metin's research ${ }^{13}$, prenatal attachment scale point average is 61.409 \pm 11.785 ; In Dereli Yilmaz's and Kizilkaya Beji ${ }^{12}$ research, prenatal attachment scale point average is high as 60.71 \pm 10.12 and 61.72 \pm 10.7 . In Armstrong and Edward's ${ }^{14}$ research, prenatal attachment scale point average is $60.7 \pm 10.1$.

Age groups, education level, and working situations and comparisons of prenatal attachment scale point average were given in Table 3. A meaningful difference was detected between features with the prenatal attachment scale $(p<0.05)$. Prenatal attachment levels of the pregnants who are in 40 and above years group, the primary school graduated, not working and having less income than outcome, living in a crowded house, and whose marriage times is more than 11 years are lower (Table 3).

There are some similar researches in literature. In Metin's ${ }^{13}$ research, a difference of prenatal attachment scale point average according to education level and marriage time is meaningful $(\mathrm{p}<0.05)$. Pregnants having education in primary school level have got lower prenatal bonding scale point average. Regarding research, Dereli Yilmaz and Kizılkaya Beji ${ }^{12}$ cited that pregnants who graduated from high school and university have got higher prenatal scale point average than primary school graduated. In light of these data, it can be said that higher education level effects prenatal bonding levels in a positive way. By continuing, it was detected that that prenatal bonding grade in 1-2 years of marriage times are higher is caused by their first birth ${ }^{13}$. In Lerum ve LoBiondo-Wood's ${ }^{15}$ research, income level and planning of pregnancy have got an effect on bonding. In Günay's ${ }^{16}$ research, the education level of pregnants shows differences according to prenatal attachment grades.

Apart from the discovery of this research, in Metin's ${ }^{13}$ research, the difference between point average is not statistically meaningful according to pregnant's age groups, working situations, and incomes ( $p>0.05)$. Lerum and LoBiondo-Wood ${ }^{15}$, cited that the age of a mother does not affect the prenatal bondings. In Dereli Yilmaz and Kizılkaya Beji's ${ }^{12}$ research, there are no differences between prenatal attachment according to economic status of pregnant, so it was evaluated like economic factors have got no effect on creating bonds between baby and mother. In the same research, there are no differences in prenatal attachment according to family types.

Comparison of prenatal attachment scale point average according to pregnancy based features of pregnants and whether having children were given in Table 3. Giving birth times of pregnants, planning situation of pregnancy, who decided the pregnancy, living children numbers, having no disabled children and pregnancy with medical treatment has got a meaningful statistical difference with prenatal attachment scale point average $(p<0.05)$; and there is no meaningful statistical difference with pregnancy month and prenatal bonding 
scale point average $(p>0.05)$. Pregnant ones whose first birth, decide pregnancy with a plan and made this decision with her husband have got higher prenatal attachment grades.

In literature, some researchers are showing parallel discoveries. In Dereli Yılmaz and Kızılkaya Beji's ${ }^{12}$ research, there are meaningful statistical differences between prenatal attachment grades of pregnant women, women who give her first birth have got higher prenatal attachment than others. In the same research, in planned pregnancies and ones who have no living children have got high prenatal bondings, the week of birth does not affect prenatal bondings. It was interpreted like a woman who planned and chose to have the right time for both herself and her husband's high prenatal bondings. Women have got any child yet follow her pregnancy sensitively, try to interpret every behavior acted by her child, and this case increases the relations and bondings. Similarly, In Günay's ${ }^{16}$ research, it is seen that prenatal bonding levels of pregnants show differences according to giving birth times and how many children they have got.

Apart from discoveries, Condon and Esuvaranathan ${ }^{17}$ determined that parity was not important in bondings. The first time carried out in couples has got second time experiences. Similarly, Berryman and Windridge ${ }^{18}$, in their researches carried out on prenatal bonding grades of 35 years old and above pregnants, the parity was not important. Just because women who got pregnant with assistant reproduction ways had been waiting for pregnancy for a long time, may have high prenatal bondings grades. Unlike discoveries of the study, in Hjelmstedt, Widström, and Collins' $s^{19}$ studies, a woman who got pregnant with in-vitro fertilization have got similar prenatal attachment with other mothers. Similarly, Hjelmstedt et al. ${ }^{19}$ suggest that there are no statistical differences between natural pregnancy and pregnancy with medical treatment.

Comparison of Prenatal Attachment Inventory Point Average according to doctor controls times during pregnancy, having education during pregnancy and making necessary tests done were given in Table 3 . There are meaningful differences between prenatal bonding scale point average and how many times she went for control, having an education, and are not making necessary tests done during her pregnancy $(p<0.05)$. Lesser number of doctor controls, ones having no education and is not making necessary tests have got lower prenatal bonding scale point average (Table 3 ).
That pregnants going for control, and having education about pregnancy and making necessary controls done provides an opportunity to track her baby's health closer, thus mother candidate who knows that her baby is raising healthy and bondings increases. A mother becomes aware of her baby in this way. The process of acceptance of the baby gets faster. Supporting the discoveries of the study, Lumley's ${ }^{20}$ study, becoming apparent after using ultrasound during pregnancy, claims an increase in recognizing baby as a person. Laxton-Kane and Slade ${ }^{21}$, claims that scanning test is an opportunity for mother for seeing her baby first time, and it increases the prenatal bondings.

Unlike this discovery, Kleinveld et al. ${ }^{22}$ offers that prenatal scanning ways increase the bondings a little, but there are no differences between ultrasound or blood tests in bondings. Similarly, in Baillie, Hewison, and Maso's ${ }^{23}$ study offers that, making necessary ultrasound scanning tests does not affect prenatal bondings.

Consequently, increasing family planning counseling is suggested in order to prevent unplanned pregnancies, especially for married and sexually active women, firstly in first-grade medical organizations. Widening prebirth preparation classes, providing participating all pregnants to these class', thus meeting education and periodical controls needs. Evaluating prenatal bonding grades since the detection of pregnancy and tracking closely of whom prenatal bondings are lower.

\section{References}

1. Okanlı A, Tortumluoğlu G, Kırpınar İ. The relationship between pregnant women perceived social support from family and problem solving skill. Anadolu Psikiyatri Dergisi 2003;4(2):98-105.

2. Muller ME. The development and testing of the prenatal attachment inventory. Western Journal of Nursing Research 1993;15(2):199-211.

3. Muller ME. Prenatal and Postnatal Attachment: A Modest Correlation. Journal of Obstetric, Gynecologic, and Neonatal Nursing 1996;25(2):161-6.

4. Sitrin L. Parental coping after miscarriage, stillbirth, neonatal death and infant death. Doctorate Dissertation. The California School of Professional Pschology, Alameda, 1994.

5. Cranley MS. Development of a tool for the measurement of maternal attachment during pregnancy. Nursing Research 1981;30(5):281-4.

6. Peppers LG, Knapp RJ. Maternal reactions to involuntary fetal/ infant death. Psychiatry 1980;43(2):155-9. 
7. Eswi A, Khalil A. Prenatal Attachment and Fetal Health Locus of Control among Low Risk and High Risk Pregnant Women. World Applied Sciences Journal 2012;18(4):462-71.

8. Abbasoğlu A, Atay G, İpekçi AM, Gökçay B, Candoğan ÇB, Şahin E et al. The relationship between maternal-infant bonding and infantile colic. Çocuk Sağlı̆̆ı ve Hastalıkları Dergisi 2015;58:57-61.

9. Van de Rijt-Plooij HC, Plooij PX. Distinct periods of mother infant conflict in normal development: Sources of progress and germs of pathology. Journal of Child Psychology and Psychiatry 1993;34:229-45.

10. Pearson JL, Cowan PA, Cowan CP. Adult attachment and adult child-order parent relationships. American Journal of Orthopsychiatry 1993;63(4):606-13.

11. Aluş Tokat M, Okumuş H, Dennis CL. Translation and psychometric assessment of the Breast-feeding Self-Efficacy Scale-Short Form among pregnant and postnatal women in Turkey. Midwifery 2010;26(1):101-8.

12. Dereli Yılmaz S, Kizılkaya Beji N. Turkish Version of Prenatal Attachment Inventory: A Study of Reliability and Validity. Anadolu Hemşirelik ve Sağlık Bilimleri Dergisi 2013;16(2):103-9.

13. Metin A. Examination of the relationship between perceived social support and prenatal self- assessment in pregnant. Atatürk University Programme of Nursing Master Thesis, Erzurum, 2014.

14. Armstrong K, Edwards $\mathrm{H}$. The effects of exercise and social support on mothers reporting depressive symptoms: a pilot randomized controlled trial. International Journal of Mental Health Nursing 2003;12(2):130-8.
15. Lerum CW, LoBiondo-Wood G. The relationship of maternal age, quickening, and physical symptoms of pregnancy to the development of maternal-fetal attachment. Birth 1998;16(1):13-7.

16. Günay P. Examine the variables of Pregnant women associated with prenatal attechement level. Haliç Univesity Instute of Social Sciencess Master Thesis, 2015.

17. Condon JT, Esuvaranathan V. The influence of parity on the experience of pregnancy: a comparison of first- and second-time expectant couples. The British Journal of Medical Psychology 1990;63(Pt 4):369-77.

18. Berryman JC, Windridge KC. Pregnancy after 35 and attachment to the fetus. J Reprod Infant Psychol 1996;14(2):133-43.

19. Hjelmstedt A, Widström AM, Collins A. Attachment in women who conceived after in vitro fertilization and women who conceived naturally. Birth 2006;33(4):303-10.

20. Lumley JM. Through a glass darkly: Ultrasound and prenatal bonding. Birth 1990;17(4):214-7.

21. Laxton-Kane $M$, Slade $P$. The role of maternal prenatal attachment in a woman's experience of pregnancy and implications for the process of care, Journal of Reproductive and Infant Psychology 2002;20(4):253-66.

22. Kleinveld JH, Timmermans DR, Van den Berg M, Van Eijk JT, Ten Kate LP. Does offering and performing prenatal screening inf uence women's attachment to their unborn child? A longitudinal randomized controlled trial. Prenatal Diagnosis 2007;27(8):757-64.

23. Baillie C, Hewison J, Maso NG. Should ultrasound scanning in pregnancy be routine? Journal of Reproductive and Infant Psychology 1999;17(2):149-57. 